International Journal of Electrical and Power Engineering 4 (1): 27-31, 2010

ISSN: 1990-7958

(C) Medwell Journals, 2010

\title{
Comparative Study of Three Cathodic Electron Acceptors on the Performance of Medatiorless Microbial Fuel Cell
}

\author{
${ }^{1} \mathrm{~N}$. Guerrero-Rangel, ${ }^{1}$ J.A. Rodríguez-de la Garza, ${ }^{1}$ Y. Garza-García, ${ }^{1}$ L. J. Ríos-González, \\ ${ }^{1}$ G.J. Sosa-Santillán, ${ }^{1}$ I.M. de la Garza-Rodríguez, ${ }^{2}$ S.Y. Martínez-Amador, \\ ${ }^{1}$ M.M. Rodriguez-Garza and ${ }^{1} \mathrm{~J}$. Rodríguez-Martínez \\ ${ }^{1}$ Departamento de Biotecnología, Facultad de Ciencias Químicas, \\ Universidad Autónoma de Coahuila, Boulevard V. Carranza e Ing. J. Cárdenas Valdés, \\ Col. República Oriente, Saltillo, Coahuila, C.P. 25280, México \\ ${ }^{2}$ Departamento de Botánica, Universidad Autónoma Agraria Antonio Narro, \\ Calzada Antonio Narro 1923, Buenavista, Saltillo, Coahuila, México
}

\begin{abstract}
Microbial Fuel Cells (MFC) are capable of converting the chemical energy stored in the chemical compounds in a biomass to electrical energy with the aid of microorganisms. A better understanding of the relationship between the microbiological and electrical aspects of fuels cells is needed prior to successful MFC application. MFC constructed employing low-cost materials (salt bridge, graphite electrodes) without addition of any toxic mediators and using glucose $\left(3 \mathrm{~g} \mathrm{~L}^{-1}\right)$ as substrate and three different electron acceptors potassium permanganate $\left(\mathrm{KMnO}_{4}\right)$, potassium ferricyanide $\left(\mathrm{K}_{3}\left[\mathrm{Fe}(\mathrm{CN})_{6}\right]\right)$ and potassium dichromate $\left(\mathrm{K}_{2} \mathrm{Cr}_{2} \mathrm{O}_{7}\right)$ in the cathode chamber without $\mathrm{pH}$ adjustment was assessed in the present study. The results showed that MFC performance with $\mathrm{KMnO}_{4}$ was superior than $\mathrm{K}_{3}\left[\mathrm{Fe}(\mathrm{CN})_{6}\right]$ and $\mathrm{K}_{2} \mathrm{Cr}_{2} \mathrm{O}_{7}$. Maximum voltage generation (OCV) and power density for $\mathrm{KMnO}_{4}$ were $1.04 \mathrm{~V}$ and $7.29 \mathrm{~mW} \mathrm{~m}{ }^{-2}$. Performance of $\mathrm{MFC}$ with $\mathrm{K}_{3}\left[\mathrm{Fe}(\mathrm{CN})_{6}\right]$ and $\mathrm{K}_{2} \mathrm{Cr}_{2} \mathrm{O}_{7}$ was much lower with a OCV and power density of $0.71 \mathrm{~V} ; 0.92 \mathrm{~mW} \mathrm{~m}^{-2}$ and $0.56 \mathrm{~V} ; 0.79 \mathrm{~mW} \mathrm{~m}^{-2}$, respectively. Demonstrating that $\mathrm{KMnO}_{4}$ can be used as an effective cathodic electron acceptor to enhance power output on MFC.
\end{abstract}

Key words: Cathodic electron acceptor, electrical energy, microbial fuel cell, potassium permanganate, power density, voltage

\section{INTRODUCTION}

Recently, Microbial Fuel Cells (MFCs) have emerged as a promising yet challenging technology. MFCs are considered to be an alternative sustainable technology to meet increasing energy needs, simultaneously accomplishing efficient wastewater treatment and electricity generation (Aelterman et al., 2006; Lu et al., 2009; Ahn and Logan, 2010). In this technology, bacteria act as biocatalysts to oxidize organic and inorganic matter and generate current (Oh et al., 2004; Li et al., 2008). Electrons produced by bacteria from these substrates migrate to the anode (negative terminal) in the anodic chamber and flow to the cathode (positive terminal) trough a conductive material and a resistor, or operated under a load (i.e., producing electricity that runs a device). Electrons can be transferred to the anode by electron mediators or shuttles (Rabaey et al., 2005) by direct membrane associated electron transfer (Bond and Lovley, 2003) or by so-called nanowires (Reguera et al., 2006) produced by the bacteria or perhaps by other as yet undiscovered means.

For a long period of time, MFCs remained a scientific curiosity because of their limited efficiency (Schröder, 2007). At present, power outputs in MFC are being increased due to the integration of both microbial and electrochemical aspects, important hurdles have been tackled (Oh et al., 2004; Rabaey et al., 2005). Nevertheless, several bottlenecks still exist, each requiring an appropriate strategy development.

Previous reports have shown that the performance of a MFC is determined by several factors (Pham et al., 2004). They are: microbial activities oxidizing fuels in the anode, electron transfer from microbial cells to the anode, proton transfer from the anode to cathode through the selective membrane, resistance of the circuit used to

Corresponding Author: N. Guerrero-Rangel, Departamento de Biotecnología, Facultad de Ciencias Químicas, Universidad Autónoma de Coahuila, Boulevard V. Carranza e Ing. J. Cárdenas Valdés, Col. República Oriente, Saltillo, Coahuila, C.P. 25280, México 
transmit electrons from the anode to the cathode and cathode reaction. Among them, oxygen consumption is considered to be the most serious factor to limit the performance of $\mathrm{MFC}$. Increasing efforts have been devoted to optimizing the reduction of the electron acceptor on the cathode electrode surface. So far, oxygen is still widely used as the electron acceptor in most MFC applications due to its availability in the environment and its high redox potential (Cheng et al., 2006; Clauwaert et al., 2007; Li et al., 2009). However, the main disadvantages is the poor contact between gaseous oxygen and cathode electrode as well as the slow rate of oxygen reduction on the surface of carbon electrodes hinder MFC application ( $\mathrm{Li}$ et al., 2009). In order to eliminate oxygen limitation, the dissolved oxygen concentration in the cathode should be kept high, which requires increased power consumption and results in more oxygen diffusion into the anode. Diverse cathode electron acceptors with improved catalytic activity have been proposed to overcome this problem (Pham et al., 2004; Oh et al., 2004; Tartakovsky and Guiot, 2006; Youet al., 2006).

In the study, a two-chamber MFC was constructed, using low cost construction material, reused graphite rod electrode, two plastic bottle linked with salt bridge. Three cathodic electron acceptors were assessed (potassium dichromate, potassium permanganate and potassium ferricyanide), comparison between the three electron acceptors was established by means of voltage generation (OCV open circuit voltage) and power density.

\section{MATERIALS AND METHODS}

Experimental set-u: The two-chamber MFC were constructed with two plastic bottles with a volume of $1000 \mathrm{~mL}$ each. Flastic bottles were per forated and attached an inner screw thread joint to each bottle. An external thread joint ( 4 in length) was use to constructed the agar salt bridge (agar $3 \%, \mathrm{KC1} 100 \mathrm{Mm}$ ). Graphite rods (Ø) $0.8 \times 4 \mathrm{~cm}$ length, surface area $10.55 \mathrm{~cm}^{2}$ ) were used as electrodes for both chambers and connected using coated copper wire 22 gauge and sealed with silicon. Anodic chamber was inoculated with $250 \mathrm{~mL}$ of anaerobic sludge obtained from a UASB reactor and $500 \mathrm{~mL}$ of medium containing glucose as sole carbon source $\left(3 \mathrm{~g} \mathrm{~L}^{-1}=\right.$ $\left.850 \mathrm{mg} \mathrm{COD} \mathrm{L}{ }^{-1}\right)$ in a mineral medium $\mathrm{Na}_{2} \mathrm{H}_{2} \mathrm{PO}_{4} .2 \mathrm{H}_{2} \mathrm{O}$ (0.53 $\left.\mathrm{g} \mathrm{L}^{-1}\right), \mathrm{NH}_{4} \mathrm{Cl}\left(0.3 \mathrm{~g} \mathrm{~L}^{-1}\right), \mathrm{MgCl}_{2} \cdot 2 \mathrm{H}_{2} \mathrm{O}\left(0.1 \mathrm{~g} \mathrm{~L}^{-1}\right)$, $\mathrm{CoCl}_{2} .6 \mathrm{H}_{2} \mathrm{O}\left(0.08 \mathrm{gL}^{-1}\right), \mathrm{NiCl}_{2} 6 \mathrm{H}_{2} \mathrm{O}\left(0.02 \mathrm{gL}^{-1}\right)$ and $\mathrm{ZnCl}_{2}$ (0.001 $\left.\mathrm{g} \mathrm{L}^{-1}\right)$. Cathodic solutions (20 $\mathrm{Mm}$ each) were prepared with analytical-grade potassium permanganate $\left(\mathrm{KMnO}_{4}\right)$, potassium ferricyanide $\left(\mathrm{K}_{3}\left[\mathrm{~F}(\mathrm{CN})_{3}\right]\right)$ and potassium dichromate $\left(\mathrm{K}_{2} \mathrm{Cr}_{2} \mathrm{O}_{7}\right)$ chemicals. No mediators
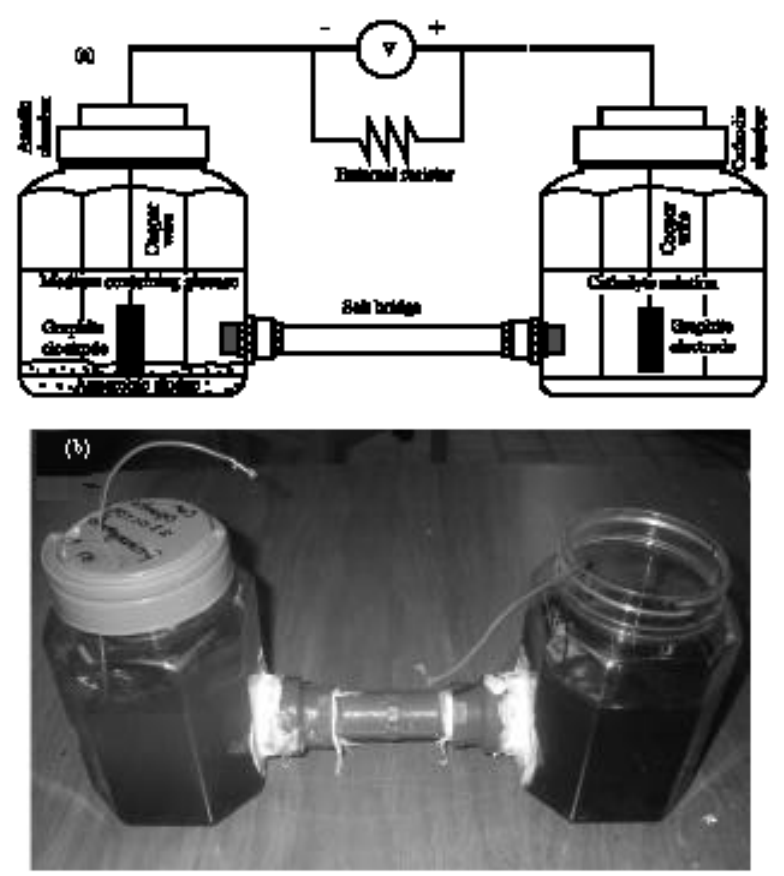

Fig. 1: Schematic (a) and picture (b) of the two-chamber $\mathrm{MFC}$ used on this study

were used in the anodic chamber of the MFC. Evaluation of $\mathrm{MFC}$ was conducted at room temperature $\left(18-23^{\circ} \mathrm{C}\right)$. The schematic and picture of two-chamber $\mathrm{MFC}$ are illustrated in Fig. 1a and b.

Measurements and calculations: Open Circuit Voltage (OCV) wasmeasured every $60 \mathrm{~min}$ with a digital multimeter (FLUKE 287), external resistor ( $4.7 \approx 5 \mathrm{K \Omega}$ ) was connected to determined current as describe by Schaetzle et al. (2009). The extemal resistor variation was in a range of

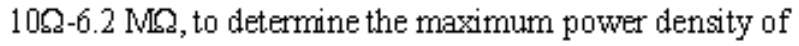
the two-chamber $\mathrm{MFC}\left(\mathrm{mW} \mathrm{m}^{-2}\right)$ according to $\mathrm{Eq} .1$ (Loganet al., 2006), where V (volts) denotes the voltage, I (mA) the current and $A\left(\mathrm{~m}^{2}\right)$ is the surface area of the electrode. The glucose overall removal as COD was determined as describe by Rodriguez-Martínez et al. (2005):

$$
\mathrm{P}=\frac{\mathrm{VI}}{\mathrm{A}}
$$

\section{RESULTS AND DISCUSSION}

Electricity generation in a two-chamber MFC using potassium permanganate, potassium ferricyanide and potassium dichromate as electron acceptors: the twochamber MFC were operated in batch mode by adding glucose as substrate ( $3 \mathrm{mg} \mathrm{L}^{-1}$ glucose $\approx 854 \pm 2 \mathrm{~g} \mathrm{O}_{2} \mathrm{~L}^{-1}$ ) 
in the anode chamber and three different electrolyte solution were compared as electron acceptors in the cathode chamber, potassium permanganate $\left(\mathrm{KMnO}_{4}\right)$, potassium ferricyanide $\left(\mathrm{K}_{3}\left[\mathrm{Fe}(\mathrm{CN})_{6}\right]\right)$ and potassium dichromate $\left(\mathrm{K}_{2} \mathrm{Cr}_{2} \mathrm{O}_{7}\right)$.

Figure 2 shows the voltage (OCV) generated for each case after $814 \mathrm{~h}$. During the first $48 \mathrm{~h} \mathrm{OCV}$ increased rapidly for all cases, the highest maximum OCV $(1.07 \mathrm{~V})$ was achieved in MFC using $\mathrm{KMnO}_{4}$ as electron acceptor. While, $\mathrm{K}_{3}\left[\mathrm{Fe}(\mathrm{CN})_{6}\right]$ and $\mathrm{K}_{2} \mathrm{Cr}_{2} \mathrm{O}_{7}$ only generated 0.71 and $0.56 \mathrm{~V}$, respectively (Table 1 ). No $\mathrm{pH}$ decreasing adjustment were made as it has been described in early reports (Zhao et al., 2005; You et al., 2006; Li et al., 2008 , 2009) that low $\mathrm{pH}$ values lead to an increase of cathode potential, since low $\mathrm{pH}$ induces a higher radical yield. As described by You et al. (2006) Eq. 2 and 3 illustrate the fact that in acidic condition, $\mathrm{MnO}_{4}$ has a much higher oxidation potential than in alkaline conditions.

$$
\begin{gathered}
\mathrm{MnO}_{4}^{-}+4 \mathrm{H}^{+}+3 \mathrm{e}^{-} \rightarrow \mathrm{MnO}_{2}+2 \mathrm{H}_{2} \mathrm{O}, \quad \mathrm{E}^{0}=1.70 \mathrm{~V} \\
\mathrm{MnO}_{4}^{-}+2 \mathrm{H}_{2} \mathrm{O}+3 \mathrm{e}^{-} \rightarrow \mathrm{MnO}_{2}+4 \mathrm{OH}^{-}, \quad \mathrm{E}^{0}=0.59 \mathrm{~V}
\end{gathered}
$$

Power and current density: By varying the circuit resistance from $10 \Omega-6.2 \mathrm{M} \Omega$, a maximum current density of $6.6 \mu \mathrm{A} \mathrm{cm}^{-2}$ for the case of $\mathrm{KMnO}_{4}$ as electron acceptor was obtained, being more than an order of magnitude higher than the other cases studied $\left(\mathrm{K}_{3}\left[\mathrm{Fe}(\mathrm{CN})_{6}\right.\right.$ and $\mathrm{K}_{2} \mathrm{Cr}_{2} \mathrm{O}_{7}$ ) with a maximum power density of $7.29 \mathrm{~mW} \mathrm{~m}^{-2}$ (Table 1 and Fig. 3). Similar results were reported by Mohan et al. (2008) were maximum power density achieved was $9.3 \mathrm{~mW} \mathrm{~m}^{-2}$ using methylene blue ( $0.03 \mathrm{mM}$ as optimum concentration) as mediator, with the difference that no mediators were used on the present study as mentioned above. Mediators trap and draw the electrons from membrane-bound reactions involving proton and electron transfer and supply those electrons to the anode electrode which is at a lower potential than the mediator itself. Since the surface area of the electrode is not sufficient to cover all of the growing bacteria, mediator acts as electron shuttles. However, the toxicity and instability of synthetic mediators limit their applications in MFCs.

The maximum power density and current reported here are modest compared with MFC using a proton exchange membranes, due to higher internal resistance of the salt bridge system as describe by Min et al. (2005), where comparison between MFC with two different selective membranes were conducted (proton exchange
Table 1: Electricity generation (OCV), power outputs and COD removal for $\mathrm{KMnO}_{4}, \mathrm{~K}_{3}\left[\mathrm{Fe}(\mathrm{CN})_{6}\right]$ and $\mathrm{K}_{2} \mathrm{Cr}_{2} \mathrm{O}_{7}$ as electrolyte cathodic solution

\begin{tabular}{|c|c|c|c|}
\hline $\begin{array}{l}\text { Cathodic } \\
\text { acceptor }\end{array}$ & $\begin{array}{l}\text { OCV } \\
\text { (volts) }\end{array}$ & $\begin{array}{c}\text { Power } \\
\text { density }\left(\mathrm{mW} \mathrm{m}^{-2}\right)\end{array}$ & $\begin{array}{c}\text { COD } \\
\text { removal }(\%)\end{array}$ \\
\hline $\mathrm{KMnO}_{4}$ & 1.04 & 7.29 & $95 \pm 1.5$ \\
\hline $\mathrm{K}_{3}\left[\mathrm{Fe}(\mathrm{CN})_{6}\right]$ & 0.71 & 0.92 & $95 \pm 1.5$ \\
\hline$\underline{\mathrm{K}_{2}} \mathrm{Cr}_{2} \mathrm{O}_{7}$ & 0.56 & 0.79 & $95 \pm 1.5$ \\
\hline
\end{tabular}
$\mathrm{KMnO}_{4}, \mathrm{~K}_{3}\left[\mathrm{Fe}(\mathrm{CN})_{6}\right]$ and $\mathrm{K}_{2} \mathrm{Cr}_{2} \mathrm{O}_{7}$ in a two-chamber MFC after $814 \mathrm{~h}$

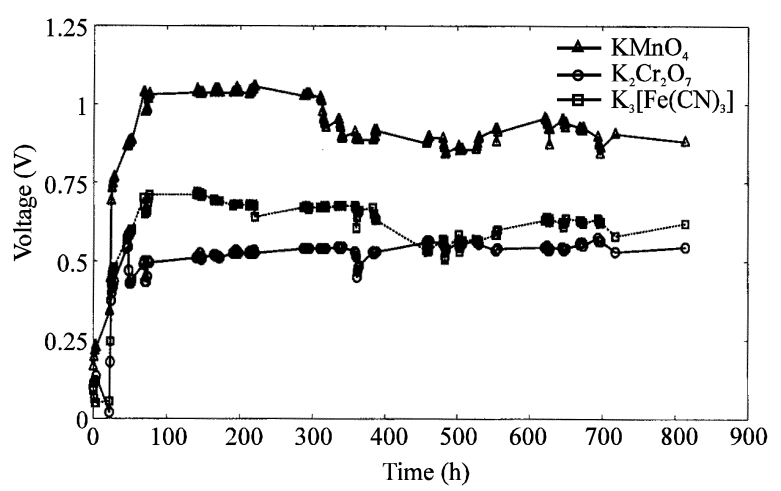

Fig. 2: Comparison of voltage (OCV) generation in two-chamber MFC using three different cathodic electron acceptors $\left(\mathrm{KMnO}_{4}, \mathrm{~K}_{3}\left[\mathrm{Fe}(\mathrm{CN})_{6}\right]\right)$, $\mathrm{K}_{2} \mathrm{Cr}_{2} \mathrm{O}_{7}, 20 \mathrm{mM}$ each); (3 $\mathrm{mg} \mathrm{L} \mathrm{L}^{-1}$ glucose $\approx$ $854 \pm 2 \mathrm{~g} \mathrm{O}_{2} \mathrm{~L}^{-1}$ )

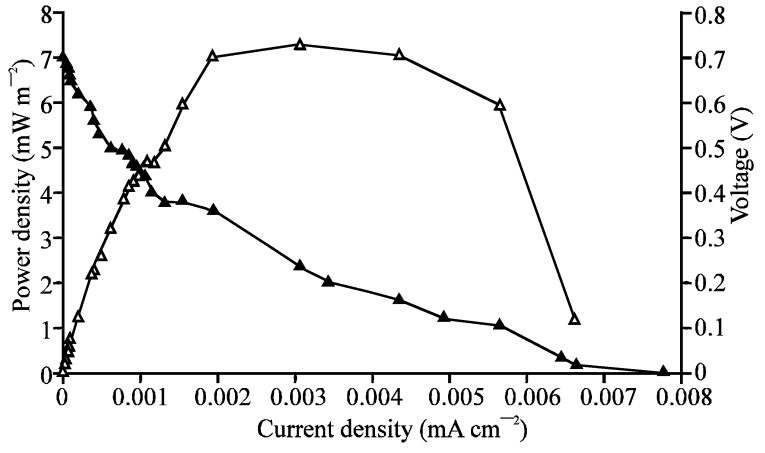

Fig. 3: Polarization and power curves in two-chamber MFC using $\mathrm{KMnO}_{4}(20 \mathrm{mM})$, as cathodic electron acceptor $\left(3 \mathrm{mg} \mathrm{L}^{-1}\right.$ glucose $\approx 854 \pm 2 \mathrm{~g} \mathrm{O}_{2} \mathrm{~L}^{-1}$ ). $\mathrm{K}_{3}\left[\mathrm{Fe}(\mathrm{CN})_{6}\right]$ and $\mathrm{K}_{2} \mathrm{Cr}_{2} \mathrm{O}_{7}$ polarization and power curves are not shown on Fig. 3 due to the great difference compared to $\mathrm{KMnO}_{4}$

membrane vs. salt bridge), the low power output by the MFC with a salt bridge is directly attributed to the high internal resistance $(19920 \pm 50 \Omega)$ compared to the low internal resistance by the MFC with proton exchange membrane $(1286 \pm 1 \Omega)$. However, the results obtained in this study are found to be very promising for a salt bridge two-chamber MFC. 
$\mathrm{KMnO}_{4}$ can be used as an effective cathodic electron acceptor in MFC, achieving a higher power density compared with other electron acceptors such as $\mathrm{K}_{3}\left[\mathrm{Fe}(\mathrm{CN})_{6}\right]$ and $\mathrm{K}_{2} \mathrm{Cr}_{2} \mathrm{O}_{7}$. Additionally $\mathrm{KMnO}_{4}$ is environment-friendly oxidant in comparison.

\section{CONCLUSION}

The influences of cathodic electron acceptor solutions (cathode solutions) on the power generation of two-chamber MFC were investigated in this study. The results show that optimizing power generation in MFC requires maximizing proton transport rates, the OCP value depends on the type of electron acceptor used.

As $\mathrm{KMnO}_{4}$ demonstrated to be a good option as cathodic electron acceptor, producing higher $\mathrm{OCV}$ and power density than $\mathrm{K}_{3}\left[\mathrm{Fe}(\mathrm{CN})_{6}\right]$ and $\mathrm{K}_{2} \mathrm{Cr}_{2} \mathrm{O}_{7}$. In order to improve the power generation of MFCs, it is critical to elucidate the limiting factor for power generation.

One efficient approach to understand the limiting factor is to systematically compare these factors for MFC performance, factors such as distance between the electrodes, surface area of the electrodes and different selective membrane to achieve a substantial reduction on internal resistance of the system will be studied further to check the efficiency of the same.

\section{ACKNOWLEDGEMENTS}

To de Mexican Council of Science and Technology (CONACYT) for providing scholarship to Guerrero-Rangel for carrying out this research as a part of her Master's thesis.

\section{REFERENCES}

Aelterman, P., K. Rabaey, P. Clauwaert and W. Verstraete, 2006. Microbial fuel cells for wastewater treatment. Water Sci. Technol., 54: 9-15.

Ahn, Y. and B.E. Logan, 2010. Effectiveness of domestic wastewater treatment using microbial fuel cells at ambient and mesophilic temperatures. Bioresour. Technol., 101: 469-475.

Bond, D.R. and D.R. Lovley, 2003. Electricity production by Geobacter sulfurreducens attached to electrodes. Applied Environ. Microbiol., 69: 1548-1555.

Cheng, S., H. Liu and B.E. Logan, 2006. Increased performance of single-chamber microbial fuel cells using an improved cathode structure. Electrochem. Commun., 8: 489-494.
Clauwaert, P., D. van der Ha, N. Boon, K. Verbeken, M. Verhaege, K. Rabaey and W. Verstraete, 2007. Open air biocathode enables effective electricity generation with microbial fuel cells. Environ. Sci. Technol., 41: 7564-7569.

Li, J., Q. Fu, Q. Liao, X. Zhu, D.D. Ye and X. Tian, 2009. Persulfate: A self-activated cathodic electron acceptor for microbial fuel cells. J. Power Sour., 194: 269-274.

Li, Z., X. Zhang and L.L. Lecheng, 2008. Electricity production during the treatment of real electroplating wastewater containing $\mathrm{Cr} 6+$ using microbial fuel cell. Process Biochem., 43: 1352-1358.

Logan, B., B. Hamelers, R. Rozendal, U. Schröder and J. Keller et al., 2006. Microbial fuel cells: Methodology and technology. Environ. Sci. Technol., 40: 5181-5192.

Lu, N., S.G. Zhou, L. Zhuang, J.T. Zhnag and J.R. Ni, 2009. Electricity generation from starch processing wastewater using microbial fuel cell technology. Biochem. Eng. J., 43: 246-251.

Min, B., S. Cheng and B.E. Logan, 2005. Electricity generation using membrane and salt bridge microbial fuel cells. Water Res., 39: 1675-1686.

Mohan, Y., M.M.S. Kumar and D. Das, 2008. Electricity generation using microbial fuel cells. Int. J. Hydrogen Energ., 33: 423-426.

Oh, S., B. Min and B. Logan, 2004. Cathode performance as a factor in electricity generation in microbial fuel cells. Environ. Sci. Technol., 38: 4900-4904.

Pham, H.T., J.K. Jang, I.S. Chang and B.H. Kim, 2004. Improvement of cathode reaction of a mediatorless microbial fuel cell. J. Microbiol. Biotechnol., 14: 324-329.

Rabaey, K., N. Boon, M. Hofte and W. Verstraete, 2005. Microbial phenazine production enhances electron transfer in biofuel cells. Environ. Sci. Technol., 39: 3401-3408.

Reguera, G., K.P. Nevin, J.S. Nicoll, S.F. Covalla, T.L. Woodard and D.R. Lovley, 2006. Biofilm and nanowire production leads to increased current in Geobacter sulfurreducens fuel cells. Applied Environ. Microbiol., 72: 7345-7348.

Rodríguez-Martínez, J., S.Y. Martínez-Amador and Y. Garza-García, 2005. Comparative anaerobic treatment of wastewater from pharmaceutical, brewery, paper and amino acid producing industries. J. Ind. Microbiol. Biotechnol., 32: 691-696. 
Schaetzle, O., F. Barriere and U. Schröder, 2009. An improved microbial fuel cell with laccase as the oxygen reduction catalyst. Energy Environ. Sci., 2: $96-99$.

Schröder, U., 2007. Anodic electron transfer mechanisms in microbial fuel cells and their energy efficiency. Phys. Chem. Chem. Phys., 9: 2619-2629.

Tartakovsky, B. and S.R. Guiot, 2006. A comparison of air and hydrogen peroxide oxygenated microbial fuel cell reactors. Biotechnol. Prog., 22: 241-246.
You, S., Q. Zhao, J. Zhang, J. Jiang and S. Zhao, 2006. A microbial fuel cell using permanganate as the cathodic electron acceptor. J. Power Sour., 162: 1409-1415.

Zhao, F., F. Harnisch, U. Schröder, F. Scholz, P. Bogdanoff and I. Herrmann, 2005. Application of pyrolysed iron (II) phthalocyanine and CoTMPP based oxygen reduction catalysts as cathode materials in microbial fuel cells. Electrochem. Commun., 7: 1405-1410. 